HANSEN, João Adolfo. O que é um livro? São Paulo: Ateliê Editorial, 2019.

\title{
João Adolfo Hansen, o leitor e o livro
}

\author{
Allan Alves*
}

Sob a direção de Marina Midori Deacto e Plinio Martins Filho, a coleção Bibliofilia proporciona ao circuito editorial brasileiro uma coletânea crítica a respeito de seu principal objeto: o livro. Produto inerente ao exercício intelectual desde as práticas de registros escritos, o livro, tal como como conhecemos, é resultado de mudanças estruturais que vão desde seu suporte tecnológico até a configuração social de distribuição e da prática de leitura em vários tempos. Atentos às transformações no circuito social contemporâneo, os diretores argumentam que a coleção "nasce em um momento de profundas mudanças no mundo do livro e do impresso, as quais tocam tanto a produção editorial, quanto as formas de transmissão da linguagem escrita e seus mecanismos de recepção [...]" (2019, contracapa).

O primeiro volume da coleção, O que é um livro?, é de autoria do professor João Adolfo Hansen. Personagem dos mais relevantes no campo dos Estudos Literários no Brasil, Hansen se destaca por suas atividades de crítica e pesquisa e por sua atuação na Universidade de São Paulo. Sua produção intelectual abrange, dentre outros campos, contribuições sobre as dimensões sociais e artísticas do período barroco, de modo geral, e a poesia de Gregório de Matos e o Brasil do século XVII, de modo particular.

\footnotetext{
* Universidade de São Paulo (USP). Doutorando no Departamento de Teoria Literária e Literatura Comparada. Possui Graduação em Letras e Filosofia. Mestre pelo programa de Literatura, Cultura e Contemporaneidade (PUC-Rio). Orcid: 0000-0001-71574472 .
} 
A cuidadosa edição - feita em capa dura sob formato reduzido - compõe um visual minimalista, conciso, de 76 páginas. Todavia, quem iniciar a leitura notará rapidamente que precisão não se confunde com austeridade de ideias. Com profunda erudição, o autor perpassa um conjunto de informações e conceitos que conduzem o leitor à reflexão múltipla sobre os modos de ser do livro em perspectiva material, histórica e interativa.

$\mathrm{Na}$ primeira perspectiva, o autor propõe pensar o livro em duas dimensões: enquanto composto material, concreto, e imaterial, resultado da linguagem. Logo nas primeiras páginas, Hansen alerta sobre a esta dupla forma de compreensão do objeto. Ao mesmo tempo que o livro é um composto físico, produzido como mercadoria de circulação, resultante de processos técnicos, intelectuais e industriais; é também objeto simbólico, pressupondo autoria, interpretação, múltiplas edições e leituras. Ao discorrer sobre essa relação, o autor argumenta acerca da condição dos sujeitos - escritores e leitores - cujos imaginários são transitórios em perspectiva histórica. Ainda hoje, o campo de circulação do livro obedece a configurações sociais hierarquizáveis. Isto é, estruturadas conforme a compreensão do valor simbólico que determinada produção escrita empreende na cultura em que circula. Por exemplo, há o livro didático, o livro técnico, o livro designado a especialistas... por isso, é fundamental compreender que, com determinada alteração de percepção social, altera-se também a condição material de produção literária:

Por exemplo, no início do século XIX, quando se inventou um novo objeto, "a criança", os irmãos Grimm inventaram um novo gênero literário, a literatura infantil, recolhendo contos populares contatos por 
camponeses alemães e franceses e adaptando-os à moralidade burguesa para a boa educação das crianças alemãs. (HANSEN, 2019, p. 11).

A partir do século XVIII, com a proliferação das academias e da posse do livro como objeto que, ao mesmo tempo, era religioso, de entretenimento, científico e de distinção social, a produção editorial ampliaria cada vez mais seus métodos para estabelecimento das condições que atendiam tanto a exigência dos intelectuais quanto o movimento do leitor consumidor. No presente, as mídias digitais configuram o instante contemporâneo, de produção especializada, que integra cada vez mais a profusão de possibilidades de escrita e de leitura - muitas vezes ultrapassando a capacidade humana de assimilação. O autor argumenta não estar totalmente esclarecido se a possibilidade exuberante da interação digital contemporânea é capaz de categorizar - entre o kitsch e a tradição - a possibilidade irrestrita do acesso mediado aos bens do saber.

Na segunda parte, Hansen trata da história e da circulação dos objetos que antecederam o que hoje conhecemos como livro. Compreende o autor que, antes de ter o formato atual a que estamos habituados, com capa, lombada, contracapa e orelhas, o que se compreende como livro existiu como escrita cuneiforme sumério-babilônica, tal como o poema de Gilgamesh. Ou como hieróglifos, em relação ao Livro dos mortos no Egito. Ou então como pictogramas, conforme o Popol Vuh, dos maias. No entanto, é no Ocidente, com os gregos, que essa prática se estabelece:

No Ocidente as primeiras formas escritas aparecem em Atenas, na metade do século VI A.C., quando o tirano Pisístrato ordenou a fixação, com letras capitais gregas, derivadas do alfabeto fenício, dos poemas homéricos, a 
Ilíada e a Odisseia, que já circulavam na oralidade uns seiscentos anos antes disso. (HANSEN, 2019, p. 22).

A partir disso, os modos de configuração dos livros mudaram lentamente. Passando por talos, pergaminhos e papiros, a constante prática da escrita daria razão ao nascimento da profissão dos copistas. Como a cópia é prática humana, passível de erro, com isso se faz necessária a criação da filologia, a fim de corrigir equívocos que a atividade legaria. Com o nascimento da atividade filológica, muitos avanços na prática da edição, escrita e distribuição ocorreriam. Assim sendo, o acúmulo de objetos escritos ocorreu de forma errante ao longo dos séculos, quer seja, caso pensemos em alguns exemplos, a partir do interesse do faraó Ptolomeu Filadelfo, criador da biblioteca de Alexandria, quer seja a partir dos copistas profissionais do império romano. A partir da confecção do códex e do estabelecimento da igreja católica, o latim se manteria a principal língua de publicação até a modernidade, com a criação de Gutemberg, que promoveria uma revolução na atividade editorial por toda Europa.

$\mathrm{Na}$ terceira parte, Hansen comenta sobre os efeitos da interação entre leitor e livro. Dialogando com diversas vertentes da Teoria da Literatura e da Filosofia, em especial a estética da recepção, de Wolfgang Iser, e o pensamento de Gilles Deleuze, o autor intenta 'pensar o intervalo 'entre', que é o intervalo existente entre o momento em que o autor inventa o texto e o tempo e o lugar em que acontece a leitura, em um campo da linguagem [...]" (HANSEN, 2019, p. 35). Para pensar o livro como objeto que só existe quando é lido, é essencial trazer de forma dialógica a compreensão do leitor, suas limitações, intenções e movimentos inconscientes. A posição do leitor como sujeito finito, histórico, que absorve do texto e o remodela, 
constrói diferentes interpretações dos mesmos textos que sobreviverão ao longo do tempo. É nesse espaço, de distância - temporal, espacial ou social - que se coadunam os elementos da interpretação do mundo. Logo, a distância entre a produção e a recepção - interação fundamental da prática de leitura conduzirá ao vazio de sentido que dará lugar à experiência. E é nesse vazio, na criação do leitor, que o arcabouço imaterial do livro sobrevive. Ademais, o autor compreende que há sempre um desnível entre a enunciação do texto e a leitura. Diante disso, a significação produzida tende sempre a uma tensão de fechamento e abertura. Ao mobilizar repertórios e associá-los a seu próprio capital simbólico, o leitor necessitaria sempre aperfeiçoar sua prática de leitura, a fim de que possa dela desfrutar com maior amplitude de sentido e clareza.

Por fim, ao inaugurar a coleção, João Adolfo Hansen proporciona a todo público uma reflexão potente e necessária, escrita em linguagem precisa - resultante de maturidade intelectual criada, sobretudo, pelo incontornável contato com os livros. Nesse sentido, $\mathbf{O}$ que é um livro? preenche uma lacuna de meta-reflexões sobre o próprio dispositivo cultural no qual circula grande parte de nossa memória. Sendo tais encontros tão raros, a obra se mostra contribuidora importante aos que compartilham o fascínio pelo mundo dos livros. 